THE POLITICAL THEORY OF NEOLIBERALISM 


\section{U R R E N C IES}

New Thinking for Financial Times

Melinda Cooper and Martijn Konings, Editors 


\title{
The Political Theory of Neoliberalism
}

\author{
THOMAS BIEBRICHER
}


STANFORD UNIVERSITY PRESS

Stanford, California

(C) 2018 by the Board of Trustees of the Leland Stanford Junior University. All rights reserved.

No part of this book may be reproduced or transmitted in any form or by any means, electronic or mechanical, including photocopying and recording, or in any information storage or retrieval system without the prior written permission of Stanford University Press.

Printed in the United States of America on acid-free, archival-quality paper Library of Congress Cataloging-in-Publication Data

Names: Biebricher, Thomas, I974- author.

Title: The political theory of neoliberalism / Thomas Biebricher.

Description: Stanford, California : Stanford University Press, 2018. I

Series: Currencies I Includes bibliographical references and index.

Identifiers: LCCN 2018016758 (print) | LCCN 2018019839 (ebook) |

ISBN 978I 503607835 I ISBN 9781503603646 (cloth : alk. paper) |

ISBN 9781503607828 (pbk. : alk. paper)

Subjects: LCSH: Neoliberalism. I Political science-Philosophy. I

Neoliberalism-European Union countries. I European Union countries-

Politics and government. I European Union countries-Economic policy.

Classification: LCC JC574 (ebook) I LCC JC574 .B54 2018 (print) ।

DDC $320.5 \mathrm{I} / 3$ - dc2 3

$\mathrm{LC}$ record available at https://lccn.loc.gov/2018016758

Typeset by Kevin Barrett Kane in 10/1 5 Janson

Cover design by George Kirkpatrick 